\title{
Sources of variability in lactational performance
}

\author{
By J. D. Oldham and N. C. Friggens, Edinburgh School of Agriculture, West Mains
} Road, Edinburgh EH9 $3 J G$

Variation in lactational performance comes about as a result of variation in the nature of the animal, its environment, or with time. Table 1 lists a variety of sources of variability, classified under broad headings of variation with the animal (species, breed and individual), with time and with various aspects of the environment. The list is probably not comprehensive, but even so, it contains more issues than can be dealt with in depth here. So we have chosen to select for comment a few issues in which we have a particular interest and which are likely to interest members of this Society.

An important feature in any consideration of lactational performance must be to note that 'lactational performance' has many dimensions. There are elements of milk secretion, change in maternal state, the growth and well-being of offspring and, in species which display lactational oestrus, the initiation of a subsequent cycle of reproduction. Each of these elements of lactational performance varies depending on species, environment and time, but not usually independently of each other. So, for example, animals which are thin at parturition might adjust both the amount of food they choose to eat and their rate of milk secretion in relation to the extent and state of their body tissue reserves. There may also be metabolic adjustments which alter the likelihood of renewed conception. It is the concerted set of events which represents lactational performance. The orchestration of the various elements of overall performance is subject to a variety of controls which deal both with tactical (homeostasis) and strategic (homeorhetic) aspects of metabolism (Bauman \& Currie, 1980).

A thorough appraisal of variability in lactational performance requires knowledge of each of the different contributing elements. Unfortunately, many reports of lactation concentrate only on the milk secretory process and tend to ignore other, associated, changes. We have tried here to recognize and emphasize the multi-dimensional aspect of lactational performance, and to emphasize the important interactions between the nature of the animal and its environment in determining temporal changes in overall lactational performance.

A number of important issues are dealt with superficially or not at all. In addition to papers in this symposium, the following are useful reference sources which deal with variability in lactational performance in relation to evolutionary strategies, the thermal

Table 1. Sources of variability in lactational performance classified according to animal, environment and time

Animal factors

Between species

Between breeds within species

Between individuals

Litter size

Reproductive state
Environmental factors

Thermal environment

Nutrition

Work, exercise

Health

Milk withdrawal

Natural (litter size)

Enforced (frequency of milking)

External agents (e.g. bovine somatotrophin)
Time related factors

Age

Parity

Season

Stage of lactation 
environment, health, physiological manipulation, etc: Peaker et al. (1984), Lucey et al. (1986), Mepham (1983, 1987), McBride et al. (1988), Garnsworthy (1988).

\section{Animal variation}

In making comparisons, especially across species, an important part of the perceived variation in lactation performance lies in the nature of the method used to estimate milk yield. Oftedal (1984) refers to weight-differential, timed milking, isotope dilution and isotope transfer as the four general methods which have been used. Given appropriate care, each of these methods appears to be capable of allowing a reasonable estimation of milk yield, although there is no doubt that errors in estimation of milk yield add (and perhaps substantially) to some of the variability encountered in published reports.

There appears to be no single scaling rule to relate milk output to body size which removes all variation between species. In relation to the old adage that all animals are the same except for the differences, Oftedal (1984) identified three separate allometric groupings:

species with many young: $\quad$ in MGE $=0.812$ 1n $W+6.595$, ungulates with single young: 1n MGE $=0.731 \mathrm{nn} W+5.852$, primates with single young: $1 \mathrm{n} \mathrm{MGE}=0.666 \mathrm{ln} W+5.324$,

where MGE is the milk gross energy yield $(\mathrm{kJ} / \mathrm{d})$ and $W$ is maternal weight.

Variation between breeds within species and between animals within breeds are best documented for the most commercially important lactating animal, the dairy cow. There is substantial variation between dairy cattle breeds in absolute levels of the secretion of milk and milk constituents, although scaling of the breed average yields in relation to body size removes many of the differences. Within a breed, additive genetic variation (heritability) in the yield of milk and its constituents accounts for $24-27 \%$ of overall variability (Table 2; Maijala \& Hanna, 1974). The heritability of milk fat and milk protein concentrations is much higher than that for the yield of milk constituents. But the absolute variation in yield between individuals is much greater than the absolute variation in concentration, and it is for this reason that selection on yield of milk constituents is the main pathway for improving productivity of individuals. Heritability of milk and milk constituent yields is higher amongst dairy cow herds with high rather than low levels of mean production. It is also higher in herds with high compared with low levels of within herd variance (Hill et al. 1983). So the allocation of variability in lactational performance between genetic and environmental influences differs between herds of dairy cattle. This presumably reflects long-term differences in active management selection of those cattle by man. The extent to which genetic variation might differ with environment in other species which have undergone natural selection is not known.

Knowledge of genetic variation and the heritability of production traits in dairy cattle has been applied, of course, to further commercial aims. Objective selection has contributed to substantial variation in national breed performances over time. It is not

Table 2. Heritabilities of milk constituent yields and concentrations in dairy cattle (from Maijala \& Hanna, 1974)

$\begin{array}{lcc} & \text { Yield } & \text { Concentration } \\ \text { Milk } & 0.27 & - \\ \text { Milk fat } & 0.24 & 0.47 \\ \text { Milk protein } & 0.27 & 0.48\end{array}$


Table 3. Variation over time in the performance of dairy cattle genetically selected for total yield of fat + protein in milk

(The values are from the Edinburgh School of Agriculture Langhill Dairy herd which has a genetic control group and a selected group to enable separation of genetic and other influences on overall performance (Langhill Report, 1988))

\begin{tabular}{|c|c|c|c|c|}
\hline $\begin{array}{l}\text { Year ... } \\
\text { Group . . }\end{array}$ & $\begin{array}{c}1977 \\
\text { Selection }\end{array}$ & $\begin{array}{c}1981 \\
\text { Selection }\end{array}$ & $\begin{array}{c}1987 \\
\text { Selection }\end{array}$ & $\begin{array}{c}1987 \\
\text { Control }\end{array}$ \\
\hline Yield (kg) & 5732 & 6756 & 7905 & 6701 \\
\hline Fat $(\mathrm{g} / \mathbf{k g})$ & $38 \cdot 7$ & $42 \cdot 1$ & $42 \cdot 0$ & $41 \cdot 1$ \\
\hline Protein $(\mathrm{g} / \mathrm{kg})$ & $31 \cdot 8$ & 34.8 & $32 \cdot 5$ & $32 \cdot 7$ \\
\hline \multirow[t]{3}{*}{ Fat + protein $(\mathrm{kg})$} & 404 & 519 & 589 & 495 \\
\hline & \multicolumn{3}{|c|}{$\begin{array}{l}\text { Variation with time due to all factors } \\
\text { including genetic selection }\end{array}$} & \\
\hline & & & Variat & enetic \\
\hline
\end{tabular}
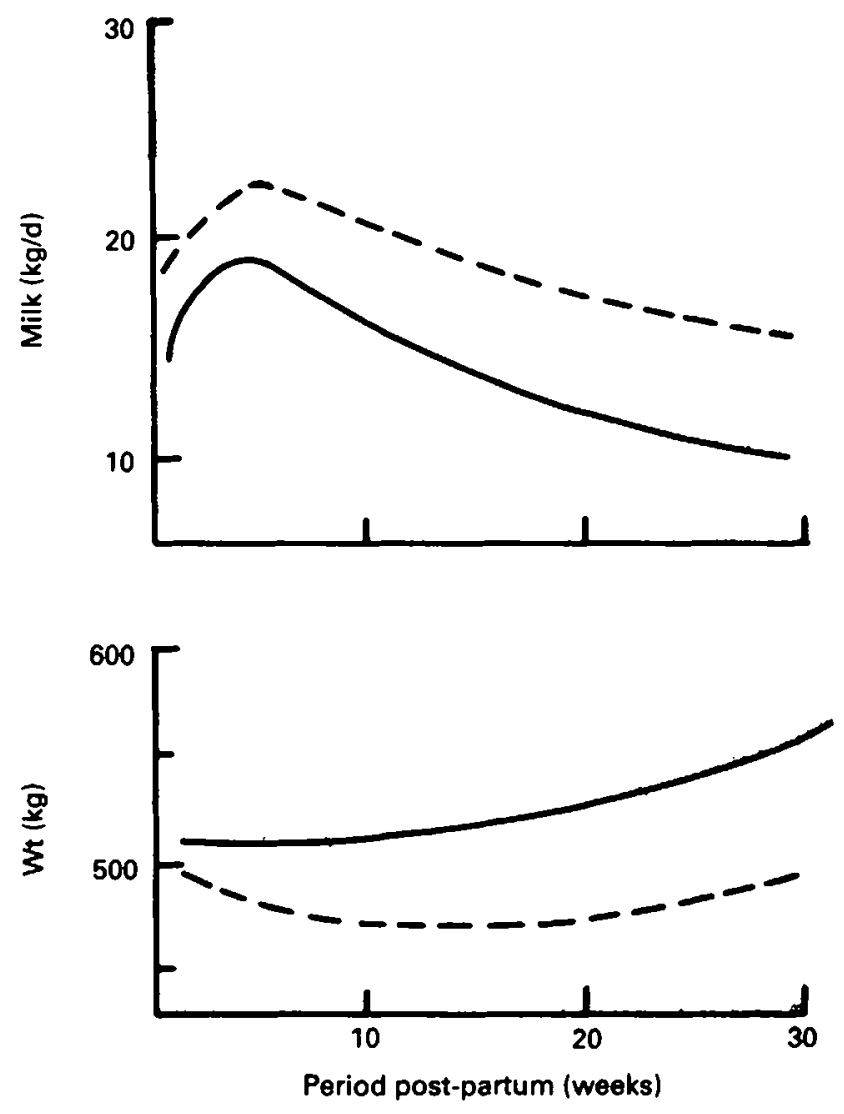

Fig. 1. Milk yield and weight change of two heifers consuming equal amounts of digestible energy from a ration containing concentrates-hay $(60: 40, w / w)$ (from values of Broster et al. 1985). 
always clear how much the increase with time in the average lactational performance of dairy cattle breeds results from genetic selection, and how much from environmental changes (e.g., improved nutrition). Some indication of the relative contributions of genetic selection and environmental development with time is shown in Table 3, using results from the Langhill Dairy Cattle Breeding Project (Langhill Report, 1988). In this instance the variation in lactational performance resulting from genetic selection has been about $2 \%$ per year.

Genetic selection for milk secretion also results in changes in other aspects of lactational performance. Thus, genetically superior animals eat more food and are likely to undergo more pronounced cycles of body tissue depletion and repletion than lower yielding counterparts (Simm \& Neilson, 1986; Holmes, 1988). In animals of similar size, eating the same amount of food, differences in secretion of milk will be counter-balanced by differences in accumulation (or loss) of body tissue. Fig. 1 shows the extent to which individual animals, offered the same ration of a given diet, can differ. In describing the relationships between milk secretory performance and food consumption in animals given ad lib. access to food it is probably more correct to say that differences in milk secretory performance are an important source of variation in ad lib. food consumption than vice versa. This, of course, does not deny that dietary allowance is an important source of variation in lactational performance where animals are rationed within ad lib. food consumption.

In order to account for individual differences in overall performance it is worth considering the extent to which those individual differences originate in differences in maintenance metabolism or milk secretory capacity, or both, and depletion and repletion of body tissue reserves.

(a) Maintenance. There may be variation between individuals as well as between breeds in the efficiency with which nutrients (food energy) are used for maintenance processes (Taylor et al. 1986b). Ion transport is a major contributor to maintenance energy costs (Milligan \& Summers, 1986) and has been found, in duodenal mucosa, to be enhanced in lactation in cows, although this may be as much the result of altered food consumption as a direct reflection of changed physiological state (McBride \& Milligan, 1984). Genetic variations in ion transport costs have been identified as a result of selection for growth in sheep, but analogous differences in lactation have yet to be sought or identified. Because of the manner in which they are calculated, conventional estimates of maintenance energy requirements of lactating cattle are assumed simply to be a function of metabolic body size and energy density of the diet, although it is noted by Agricultural Research Council (1980) that the metabolic rate of milking cows is higher than that of dry animals, which at least keeps open the possibility that there is variability between individuals in maintenance energy needs.

(b) Milk secretion. Variation between individuals in milk secretion is ultimately a function of the number of secretory cells and the amount produced by each cell. Mammary growth can be influenced by nutrition before puberty (Johnsson, 1988). But the majority of mammary growth and development occurs in adult life. Contrary to earlier belief, cell proliferation is not complete at parturition (Knight, 1984, 1989) and there are developments in the gland through successive cycles of mammary cell proliferation, lactogenesis and involution.

From measurements made on rats, Knight (1984) suggested that about $75 \%$ of the early lactation increase in milk yield could be ascribed to change in cell number, and only $25 \%$ to change in cell activity. Whether the same proportionate contributions apply to between animal differences at a stage of lactation is not known. The metabolic background to differences between individuals in the balance of nutrient deposition in 
Table 4. Variation in milk yield, milk constituent concentration and milk constituent yield with lactation number in cows of defined genetic merit (cow genetic index $>600$; Langhill Report (1988))

$\begin{array}{lrrrrr}\text { Lactation no. ... } & 1 & 2 & 3 & 4 & 5 \\ \text { Yield (kg) } & & & & & \\ \text { Milk } & 6736 & 8017 & 8624 & 9107 & 9159 \\ \text { Milk fat } & 286 & 337 & 366 & 388 & 387 \\ \text { Milk protein } & 226 & 273 & 284 & 298 & 294 \\ \text { Concentration }(\mathrm{g} / \mathrm{kg}) & & & & & \\ \quad \text { Milk fat } & 42 \cdot 4 & 42 \cdot 1 & 42 \cdot 4 & 42 \cdot 6 & 42 \cdot 2 \\ \text { Milk protein } & 33 \cdot 6 & 34 \cdot 6 & 33 \cdot 0 & 32 \cdot 7 & 32 \cdot 1\end{array}$

milk products or tissue products (Fig. 1) is reflected in pronounced differences in endocrine status, which bear reasonable correlation with milk yield and stage of lactation (Hart, 1983). Principal among these appears to be the association between bovine growth hormone (bGH) status and milk yield. Johnsson \& Hart (1986) have suggested that the speed of response in milk secretion of cattle injected with bGH makes it more likely that the response is supported by a change in cell secretory activity rather than cell number. By analogy it may, therefore, be that the endocrine environment in cattle (and presumably also other species) genetically capable of yielding different amounts of milk is conducive to enabling differences in secretory cell activity.

(c) Depletion-repletion of body tissue. Clearly the drive to use body fat reserves is an important factor influencing variation in lactation yields. Body fatness in cattle, as estimated by body condition score, appears to be controlled such that animals with amounts of fat above a 'target' value mobilize body fat reserves in support of lactation, whereas those with fatness below a 'target' value tend to eat more food and partition the majority of additional food consumed towards replenishment of body tissue reserves (Grainger et al. 1982; Neilson et al. 1983; Garnsworthy, 1988).

The extent to which body fat reserves are used to support lactation depends not only on the size of the fat reserves, but also on genetic potential of the animals. Thus, Neilson et al. (1983) found that amongst high yielding dairy cows, those which were fattest at calving lost most condition after calving and achieved the highest lactational performance in terms of milk yield, whereas amongst low yielding animals, those which were fattest at calving lost least condition (or body fat) and were the lowest yielding in terms of milk secretion.

Substantial variations in body tissue during cycles of gestation and lactation occur in many species, and there is generally more variation in fat than in protein (Oldham, 1986). Genetic differences in tissue protein repletion and depletion in lactation have not been reported.

\section{Time related variability}

Age, parity, stage of the lactation-reproduction cycle and calendar season are all time factors which can influence overall lactational performance.

In most species, parity appears to be more important than age in determining the amount of milk secreted in successive lactations. In cows, lactation yields increase progressively up to lactation no. 4 (Table 4), with little or no change with parity in the fat concentration of milk and only a slight reduction in protein concentration. The animals to which Table 4 values refer were of high defined genetic index for milk production (cow 


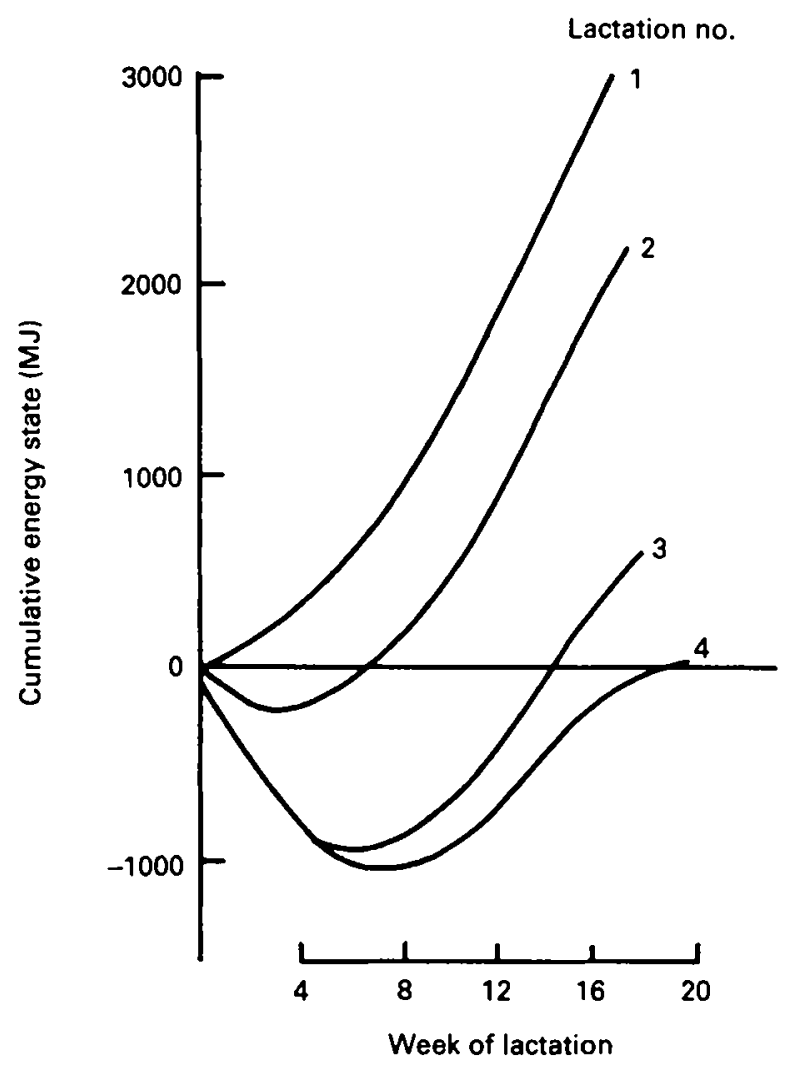

Fig. 2. Changes with lactation number in the extent and duration of cumulative energy balance (MJ) after parturition in dairy cattle of high genetic merit for milk production and offered ad lib. access to a complete mixed diet (see text and Langhill Report (1988) for details).

genetic index (CGI) greater than 600). Further analysis of the performance of these animals, which were offered high quality diets ad lib. throughout lactation, showed marked differences between parities in the extent to which they were prepared to enter energy deficit in early lactation (Fig. 2; Neilson et al. 1988). So, even in these animals with very high genetic potential for milk production, milk yield was not supported by mobilization of body tissue in the first lactation, whereas it was to an increasing extent later on. Similar observations have recently been made in pigs whose lactational performance was studied over four successive parities (Yang et al. 1989), and whose first lactation performance was substantially less than in later parities, even in pigs fed so as to have substantial reserves of fat at first parturition.

Within a lactation, variation in lactational performance is thought to be dominated by homeorhetic controls (Bauman \& Currie, 1980) which result in a lactation 'curve', characterized in many, if not all species, by a rise to a peak of production which then reduces with time. In discussing the contribution of changes in mammary cell number and activity to overall mammary secretion Knight $(1984,1989)$ has challenged the view that such a pattern of secretory activity is inevitable. But the phenomenon of continuous lactation has yet to be demonstrated. 


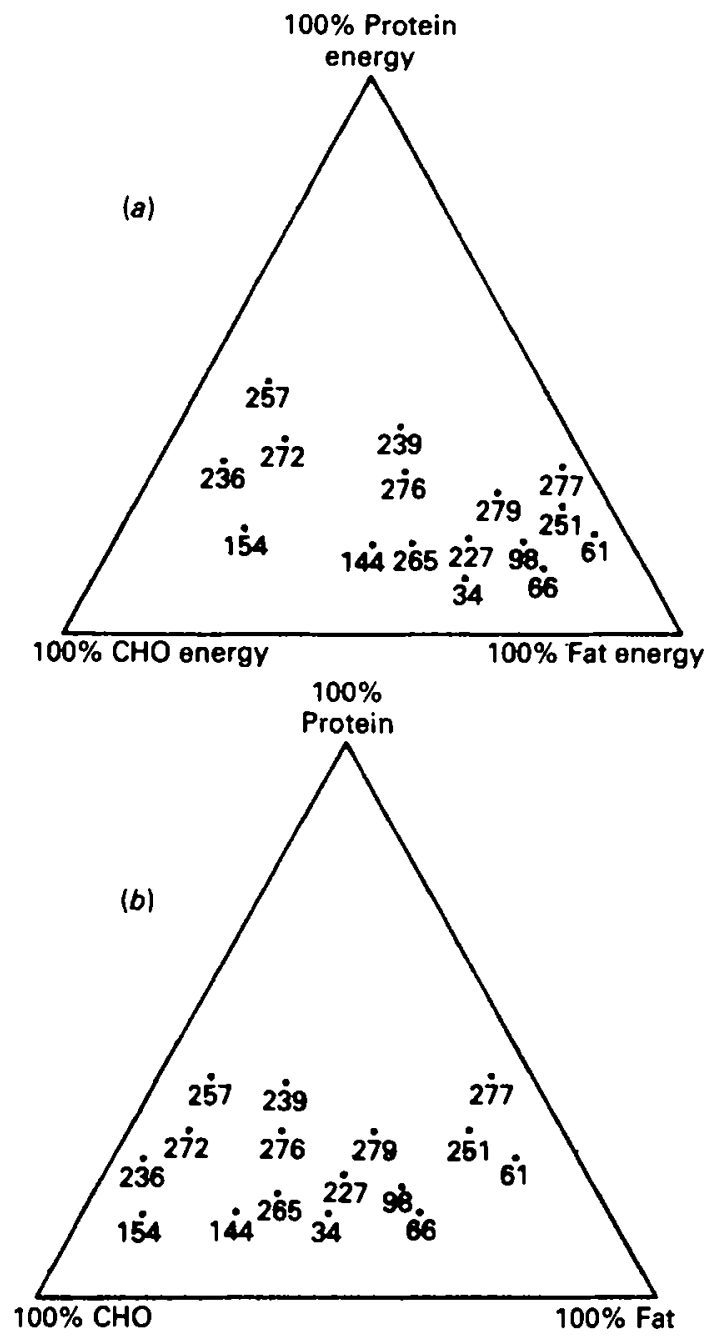

Fig. 3. The lactational performance of rats offered ad lib. diets varying in relative proportions of fat, carbohydrate $(\mathrm{CHO})$ and protein. The values describe growth of standard litters (twelve pups per litter) over days 2-12 of lactation. (a) Feed composition as proportions of energy from fat, CHO and protein, $(b)$ dry matter proportions. (See text for details; N. C. Friggens, unpublished results).

In cattle, the shape of the lactation curve is sensitive, to some extent, to nutritional manipulation. For example, diets containing a very high proportion of concentrates $(0 \cdot 9)$ have been found to support a higher peak yield, but more rapid rate of lactation decline, than diets with a lower concentrate proportion (0.6) (Broster et al. 1985). The pattern of allocation of a fixed amount of concentrate throughout lactation may not affect overall lactational performance, but it will influence the magnitude of peak milk production, rate of lactation decline and fluctuations in body state (Leaver, 1988).

\section{Environmental variability}

Many environmental factors influence lactational performance (Table 1). Of these, nutrition is, perhaps, the best recognized and most amenable to manipulation. The influence of nutrition can be both through effects of diet on the amounts and proportions 
of end-products of digestion which become available for the synthesis of milk constituents, and through their effects on the endocrine environment.

In non-ruminant species chemical description of the diet can be a good measure of nutrient availability. This is not so for ruminants, in which the rumen microbial fermentation acts to modify, considerably, the nature of end-products of digestion which are absorbed as nutrients.

We have been using simple mixtures of protein (casein), carbohydrate (starchsucrose) and fat (groundnut oil) offered $a d$ lib. to test the relationships between nutrient profile and lactational performance in Sprague-Dawley rats suckling uniform litters. Fig. 3 summarizes the results of a number of experiments (N. C. Friggens, unpublished results) which were designed to span a much wider range of nutrient proportions than has been conventional (Grimble, 1981; Naismith et al. 1982; Taylor et al. 1986a). Triangular co-ordinates are used in Fig. 3 to help display the overall effects of the profile of major nutrient classes on lactational performance as measured by pup growth.

As with other studies (Grimble, 1981; Naismith et al. 1982; Taylor et al. 1986a) lactational performance was reduced at lower dietary protein concentrations, especially when protein was $<200 \mathrm{~g} / \mathrm{kg}$ dietary dry matter. Unlike Taylor et al. (1986a) we found that increasing dietary fat at the expense of carbohydrate tended to reduce performance (N. C. Friggens, unpublished results), although differences in ad lib. food consumption in our study confound comparison with the fixed intakes used by Taylor et al. (1986a).

The most notable feature of Fig. 3 was that rats were able to sustain high levels of performance on high-fat diets which were also high in protein, but the performance of rats eating high-fat diets which were also low in protein was very poor. To a substantial extent lactational performance was unaffected by dietary carbohydrate:fat over a wide range (1:9-9:1) when protein content was high. The poor performance on diets containing low proportions of both protein and carbohydrate suggest that, at least to some extent, amino acids were being used to support a necessary carbohydrate (glucose) need when carbohydrate supply was low, but protein relatively plentiful. Similarly, at low dietary protein concentration lactational performance was superior with diets of high carbohydrate:fat ratio.

Glucose availability will have important consequences for the rate of lactose synthesis (Kuhn, 1983). A most likely explanation of poor pup performance on low protein, low carbohydrate diets is that lactose secretion was inhibited, with a consequent limitation on the volume of milk and insufficient compensatory changes in protein and fat concentrations (not measured) to sustain adequate pup growth.

Even though rats secrete milk containing a relatively low proportion of lactose, these findings suggest that glucose supply to lactating rats can be as important to the sustenance of adequate lactation as appears to be the case in ruminants (Kronfeld, 1976).

Another interesting example of the central role of glucogenic precursors is seen in the influence of exercise on lactational performance. Leng (1985) has argued that glucose availability may be a constraint to the maintenance of lactational performance during work in draught ruminants. This appears to be confirmed (Table 5) by the results of exercising suckler cows, on fixed rations, when the response to exercise was to reduce milk protein and lactose yields but to maintain fat secretion (Matthewman et al. 1989), so implicating precursors of lactose and milk protein as the limiting resource(s) during exercise.

In ruminants in particular, the influence of nutrient supply and balance on partition of available nutrients between milk secretion and body tissue deposition has been emphasized (Hart, 1983; Sutton, 1985; MacRae et al. 1988). Thus, isoenergetic supplements of nutrients given by continuous abomasal infusion can either increase 


\section{Table 5. Effects of exercise on lactational performance}

(The results are yields of milk constituents in suckler cows offered a fixed ration and either tethered (control) or walked (exercise) during part of the day around a course designed to exert an energy 'challenge' equivalent to about 12 MJ metabolizable energy (Matthewman et al. 1989))

\begin{tabular}{lccc} 
& \multicolumn{3}{c}{ Yield $(\mathrm{g} / \mathrm{d})$} \\
\cline { 2 - 4 } Expt 1 & Fat & Protein & Lactose \\
Control & 233 & 171 & 348 \\
Exercise & 228 & 156 & 283 \\
Expt 2 & & & \\
Control & 271 & 277 & 364 \\
Exercise & 272 & 256 & 331
\end{tabular}

(casein) or decrease (glucose) milk energy yield (Oldham et al. 1984). Similarly (Table 6) isoenergetic amounts, offered over complete lactations, of diets which differ in concentrate:hay ratio resulted in the secretion of amounts of total milk energy which differed by $7-8 \%$, but in which the contribution of fat energy to the total differed by $35 \%$ between the two dietary treatments. In explanation of such observations the influence of diet on the supply of glucogenic precursors (especially propionate produced from rumen fermentation of carbohydrate) and subsequent effects on insulin status has been identified as a major factor which alters the partition of fat between milk secretion and tissue deposition (Hart, 1983; Sutton, 1985). There may also be important changes in the total amounts of fat and lactose precursors which are produced as end-products of digestion with such diets, which go some way to explain changes in milk fat:lactose ratios (Sutton, 1985; Oldham \& Emmans, 1988).

Less clear than the effects of (ruminant) nutrition on the partition of energy-yielding nutrients between milk fat and body fat are the rules which govern the partition of available amino acids between milk and tissue. The results in Table 6 suggest that substantial variation can occur in milk protein (a major part of milk solids-not-fat) yields at constant intake, but different source, of digestible energy.

Also, Whitelaw et al. (1986) have shown that abomasal infusion of casein generates responses in both milk and tissue protein. This partition must vary since milk protein responses to abomasal casein supplements varies (Oldham, 1987); perhaps the state of repletion of potentially labile tissue protein (Botts et al. 1979) is an important issue here (Oldham \& Emmans, 1988).

Table 6. The amounts of energy secreted as milk fat or milk solids-not-fat (SNF) in dairy cattle offered isoenergetic rations containing concentrates and hay in different proportions

(All values in GJ (total) over 37 weeks of lactation)

$\begin{array}{lrr}\text { Concentrate-hay in ration }(w / w) \ldots & 60: 40 & 90: 10 \\ \text { Digestible energy intake } & 40 \cdot 52 & 40 \cdot 84 \\ \text { Secretion in milk } & & \\ \quad \text { Fat } & 6.07 & 4 \cdot 84 \\ \text { SNF } & 6 \cdot 18 & 8.31 \\ \text { Total } & 12.25 & 13 \cdot 15\end{array}$


The range of nutrients required to sustain lactational performance is fairly narrow (principally fat, protein and lactose precursors) and the major end-products (milk constituents, body protein and body fat) few in number. To some extent, the rules which relate descriptions of genotype to nutrient supply and nutrient use are beginning to emerge (Taylor, 1986; Oldham \& Emmans, 1988), but a number of partition rules have yet to be elucidated.

\section{Concluding remarks}

Many factors cause lactational performance to vary. In order to understand and properly represent each one, several aspects of animal performance need to be described. The most important are the secretion of milk constituents (or effects of the growth of the young before weaning, or both) and change in maternal body composition. These measures need to be taken in the context of an understanding of the nature of the mammal itself, and its biological targets.

Temporal, physical and biological influences on lactational performance yield a rich diversity of variability which presents intellectual challenges to our understanding of a process which, in totality, is perhaps a supreme example of the integration of biological events for the sustenance of life.

The authors are grateful to Dr W. H. Broster for giving access to the original values summarized in Broster et al. (1985), for further calculations. N.C.F. gratefully acknowledges postgraduate research support from MAFF.

\section{REFERENCES}

Agricultural Research Council (1980). Nutrient Requirements of Ruminant Livestock. Farnham Royal: Commonwealth Agricultural Bureaux.

Bauman, D. E. \& Currie, W. B. (1980). Journal of Dairy Science 63, 1514-1529.

Botts, R. L., Hemken, R. W. \& Bull, L. S. (1979). Journal of Dairy Science 62, 433-440.

Broster, W. H., Sutton, J. D., Bines, J. A., Broster, V. J., Smith, T. \& Siviter, J. W. (1985). Journal of Agricultural Science, Cambridge 104, 535-537.

Garnsworthy, P. C. (1988). Nutrition and Lactation in the Dairy Cow. London: Butterworths.

Grainger, C., Wilhems, G. D. \& McGowan, A. A. (1982). Australian Journal of Experimental Agriculture and Animal Husbandry 22, 9-17.

Grimble, R. F. (1981). Annals of Nutrition and Metabolism 25, 221-227.

Hart, I. C., (1983). Proceedings of the Nutrition Society 42, 181-194.

Hill, W. G., Edwards, M. R., Ahmed, M.-K. A. \& Thompson, R. (1983). Animal Production 36, 59-68.

Holmes, C. W. (1988). In Nutrition and Lactation in the Dairy Cow, pp. 195-215 [P. C. Garnsworthy, editor]. London: Butterworths.

Johnsson, I. D. (1988). In Nutrition and Lactation in the Dairy Cow, pp. 171-192 [P. C. Garnsworthy, editor]. London: Butterworths.

Johnsson, I. D. \& Hart, I. C. (1986). In Recent Advances in Animal Nutrition-1986, pp. 105-123 [W. Haresign and D. J. A. Cole, editors]. London: Butterworths.

Knight, C. H. (1984). In Physiological Strategies in Lactation. Zoological Society of London Symposium no. 51, pp. 147-170 [M. Peaker, R. G. Vernon and C. H. Knight, editors]. London: Academic Press.

Knight, C. H. (1989). Proceedings of the Nutrition Society 48, 45-51.

Kronfeld, D. S. (1976). Advances in Animal Physiology and Animal Nutrition 7, 5-26.

Kuhn, N. J. (1983). In Biochemistry of Lactation, pp. 159-176 [T. B. Mepham, editor]. Amsterdam: Elsevier. Langhill Report (1988). Langhill - Past, Present and Future. Edinburgh: Edinburgh School of Agriculture.

Leaver, J. D. (1988). In Nutrition and Lactation in the Dairy Cow, pp. 315-326 [P. C. Garnsworthy, editor]. London: Butterworths.

Leng, R. A. (1985). In Draft Power for Production. ACIAR Proceedings no. 10, pp. 69-77 [J. W. Copland, editor]. Queensland: James Cook University.

Lucey, S., Rowlands, G. J. \& Russell, A. M. (1986). Journal of Dairy Research 53, 7-15. 
McBride, B. W., Burton, J. L. \& Burton, J. H. (1988). Research and Development in Agriculture 5, (In the Press).

McBride, B. W. \& Milligan, L. P. (1984). Canadian Journal of Animal Science 64, 817-824.

MacRae, J. C., Buttery, P. J. \& Beever, D. E. (1988). In Nutrition and Lactation in the Dairy Cow, pp. 55-75 [P. C. Garnsworthy, editor]. London: Butterworths.

Maijala, K. \& Hanna, M. (1974). In Proceedings of the 1st World Congress on Genetics Applied to Livestock Production, pp. 541-563.

Matthewman, R. W., Merrit, J., Smith, A., Phillips, P. \& Oldham, J. D. (1989). Proceedings of the Nutrition Society (In the Press).

Mepham, T. B. (editor) (1983). Biochemistry of Lactation. Amsterdam: Elsevier.

Mepham, T. B. (1987). Physiology of Lactation. Milton Keynes: Open University Press.

Milligan, L. P. \& Summers, M. (1986). Proceedings of the Nutrition Society 45, 185-193.

Naismith, D. J., Richardson, D. P. \& Pritchard, A. E. (1982). British Joumal of Nutrition 48, $433-441$.

Neilson, D. R., Crawford, P. \& Oldham, J. D. (1988). Journal of Dairy Science 71, Suppl., p. 185 (abstr.).

Neilson, D. R., Whittemore, C. T., Lewis, M., Alliston, J. C., Roberts, D. J., Hodgson-Jones, L. S., Mills, J., Parkinson, H. \& Prescott, J. H. D. (1983). Animal Production 36, 321-334.

Oftedal, O. T. (1984). In Physiological Strategies in Lactation. Zoological Society of London Symposium no. 51 pp. 33-85 [M. Peaker, R. G. Vernon and C. H. Knight, editors]. London: Academic Press.

Oldham, J. D. (1986). In Proceedings of the XIII International Congress of Nutrition, pp. 607-612 [T. G. Taylor and N. K. Jenkins, editors]. London: Jobn Libbey.

Oldham, J. D. (1987). Feed Compounder January, 19-23.

Oldham, J. D., Bines, J. A. \& MacRae, J. C. (1984). Proceedings of the Nutrition Society 43, 65A.

Oldham, J. D. \& Emmans, G. C. (1988). In Nutrition and Lactation in the Dairy Cow, pp. 76-96 [P. C. Garnsworthy, editor]. London: Butterworths.

Peaker, M., Vernon, R. G. \& Knight, C. H. (editors) (1984). Physiological Strategies in Lactation. Zoological Society of London, Symposium no. 51. London: Academic Press.

Simm, G. \& Neilson, D. R. (1986). British Cattle Breeders Club Digest no. 41, pp. 65-76.

Sutton, J. D. (1985). Journal of Dairy Science 68, 3376-3393.

Taylor, J. B. (1986). A model of energy transactions in lactating rats. PhD Thesis, University of California.

Taylor, J. B., Calvert, C. C., Baldwin, R. L. \& Sainz, R. D. (1986a). Journal of Nutrition 116, $1519-1528$.

Taylor, St C. S., Thiessen, R. B. \& Murray, J. (1986b). Animal Production 43, 37-62.

Whitelaw, F. G., Milne, J. S., Ørskov, E. R. \& Smith, J. S. (1986). British Journal of Nutrition 55, 537-556.

Yang, H., Eastham, P. R., Phillips, P. \& Whittemore, C. T. (1989). Animal Production 48, 181-201. 